\title{
Pemodelan dan Verifikasi Formal Pengaruh Mobility pattern Terhadap Handoff Latency pada Jaringan WiMAX
}

\author{
I Nym Saputra Wahyu Wijaya ${ }^{* 1}$, Reza M.I. Pulungan ${ }^{2}$ \\ ${ }^{1}$ Program Studi S2 Ilmu Komputer, FMIPA UGM, Yogyakarta \\ ${ }^{2}$ Jurusan Ilmu Komputer dan Elektronika, FMIPA UGM, Yogyakarta \\ e-mail: *11inym.wahyu@gmail.com, ${ }^{2}$ pulungan@ugm.ac.id
}

\begin{abstract}
Abstrak
Untuk mengurangi handoff latency dan meningkatkan keberhasilan dari skema HHO konvensional, dilakukan pengembangan skema handover pada standard protokol WiMAX IEEE 802.16e dengan menambahkan mobility pattern. Keunggulan skema handover dengan mobility pattern adalah mengurangi handoff latency hingga 50\%, sedangkan kelemahannya sering terjadi kesalahan dalam penentuan Target base station. Verifikasi formal dilakukan untuk mengetahui kelemahan tersebut.

Skema handover dimodelkan dengan continuous-time Markov chain (CTMC). Model difokuskan untuk memperkirakan pengaruh algoritma mobility pattern terhadap handoff latency dari mekanisme Hard Handover WiMAX. Langkah-langkah untuk membangun model sebagai berikut: Mereprensentasikan state space, memberikan penomoran pada semua, menggenerasikan rate transisi matriks (infinitesimal generator). Kemudian model yang dibentuk dituangkan pada tool PRISM, untuk dilakukan verifikasi formal.

Probabilistic model checking pada penelitian melakukan pendekatan kuantitatif (qunatitative properties) dan kualitatif (qualitative properties). Verifikasi formal terhadap properti-properti yang berkaitan dengan handover pada jaringan WiMAX menunjukkan bahwa $70 \%$ dari MS yang melakukan scanning dengan mobility pattern sukses melakukan handover, $24 \%$ diantaranya melakukan scanning konvensional akibat kesalahan dalam penentuan TBS sehingga handoff latency yang dihasilkan lebih besar jika dibandingkan dengan sistem yang hanya menggunakan metode scanning konvensional.
\end{abstract}

Kata kunci-WiMAX, handover, mobility pattern, CTMC, PRISM, handoff latency

\begin{abstract}
In order to decrease handoff latency and increase the successful of HHO conventional scheme, a development of handover scheme is done in standard protocol WiMAX IEEE 802.16e by adding mobility pattern. The superiority of handover scheme with mobility pattern can reduce handoff latency up to 50\%, mean while the weakness of this scheme is a wrong act in determining target base station are often happen. Simulation can not showing the cause of that error. So, we do formal verification in to hard handover model with mobility pattern.

In this research, behaviour system is modeled with continuous-time Markov chain $(C T M C)$. The model is foccused to aproximating the influence of mobility pattern in to handoff latency from WiMAX hard handover mechanism. In order to set up a series markov chain models handover system can follow steps, such as: represents the state space, give a number in all transitions, generate the rate transition matrix (infinitesimal generator).

Probabilistic model checking in the research are using quantitative properties and qualitative properties. Formal verification concerning properties has relation with handover in WiMAX network showing that $70 \%$ from mobile station which doing scanning with mobility pattern are success doing handover. $24 \%$ of them doing scanning conventional as a result of wrongness in act determining target base station, so handoff latency which is pictured will bigger than a system that is only use conventional scanning method.
\end{abstract}

Keywords - WiMAX, handover, mobility pattern, CTMC, PRISM, handoff latency

Received July 28 $8^{\text {th }}, 2015$; Revised January ${ }^{\text {st }}$, 2016; Accepted January 20 ${ }^{\text {th }}, 2016$ 


\section{PENDAHULUAN}

$\mathrm{D}$ alam suatu jaringan yang mendukung mobilitas, aspek penting yang perlu diperhatikan adalah handover, yaitu proses perpindahan dari sebuah sel base station (BS) ke base station lainnya dengan menjamin adanya keberlangsungan komunikasi. Walaupun handover bertujuan untuk menjaga keberlangsungan komunikasi, namun mekanisme tersebut menimbulkan handoff latency yang dapat mengganggu kualitas layanan. Salah satu teknologi jaringan wireless yang mendukung mobilitas adalahWiMAX. Mekanisme handover pada standard WiMAX yang mendukung mobilitas, IEEE 802.16m diklasifikasikan menjadi dua tipe, yaitu hard handover (HHO) dan soft handover (SHO). HHO merupakan mekanisme default yang dimiliki oleh protokol IEEE 802.16m, sedangkan SHO merupakan mekanisme opsional dengan biaya dan kompleksitas yang lebih besar [1]. Untuk mengurangi handoff latency dan meningkatkan keberhasilan dari skema HHO konvensional pengembangan skema handover dilakukan pada standard protokol WiMAX IEEE 802.16e dengan menambahkan mobility pattern [2]. Keunggulan skema handover dengan mobility pattern diperkuat dengan penelitian yang membandingkan lima metode untuk mengurangi handoff latency [3]. Penelitian tersebut menyatakan bahwa mobility pattern merupakan metode terbaik untuk mengurangi handoff latency hingga 50\% dibandingkan dengan empat metode lainnya.

Probabilistic Model Checking varian dari model checking adalah sebuah prosedur otomatis untuk suatu kemunculan jika suatu properti yang diinginkan berada pada sebuah model sistem probabilistic [4]. Penelitian yang menggunakan metode formal untuk melakukan analisis skema handover sudah banyak dilakukan. Chowdhurry menyatakan, perilaku proses handover mengalami perubahan dalam domain waktu yang kontinyu terhadap kemunculan suatu event. Untuk model jaringan dengan perubahan yang terjadi dalam domain kontinyu, analisis performa secara akurat hanya mungkin dilakukan jika sistem dimodelkan dengan CTMC [5]. Penelitian yang dilakukan adalah membuat sebuah algoritma untuk meminimalkan konsumsi energi dan memodelkan skema handover tersebut dengan CTMC, namun penelitian tersebut tidak memperhatikan handoff latency.

Evaluasi performa dilakukan pada proses soff handoff dari jaringan seluler CDMA menggunakan pemodelan proses birth death yang merupakan varian dari CTMC [6]. Begitu juga dengan penelitian yang dilakukan yang menunjukkan bahwa proses birth death bisa digunakan untuk memodelkan proses $\mathrm{HHO}$ dari protokol jaringan wireless cellular untuk mengevaluasi performa dengan memperhatikan blocking probability dan dropping probability[7].

\section{METODE PENELITIAN}

Untuk membangun Model CTMC skema handover jaringan mobile WiMAX hal yang harus diperhatikan adalah representasi state, penentuan state inisial, transisi yang terjadi pada setiap state dan probabilitasnya.

\subsection{Representasi state space}

Sesuai dengan deskripsi model, terdapat dua buah model CTMC pada penelitian ini. Model yang dibangun adalah model untuk perilaku mobile station dan model untuk perilaku channel dari sebuah target base station. Masing-masing model memiliki state space yang berbeda. State space yang dimiliki oleh setiap model tergantung dari proses stokastik yang terjadi, dan untuk proses stokastik melibatkan variabel acak yang mengalami perubahan dalam waktu tertentu.

IJCCS Vol. 10, No. 1, January 2016 : 81 - 92 


\subsubsection{State space model mobile station}

State space dalam sebuah model CTMC akan saling berhubungan sesuai perubahan yang terjadi dalam setiap waktu. Hubungan tersebut dinyatakan dalam sebuah laju transisi. Laju transisi mewakilkan perubahan dari kondisi mobile station dengan observasi waktu saat ini hingga interval waktu tertentu dengan probabilitas dari pemilihan kondisi selanjutnya. Berikut adalah state space dari model CTMC mobile station:

1. State $\{$ no scan $\}$, state tersebut merupakan pengkapsulasian dari proses pengumpulan neighbor base station maupun permintaan handoff. Setelah mobile station melakukan permintaan handoff maka mobile station akan mengalami perubahan kondisi menjadi kondisi scanning. State ini diberikan penomoran sebagai state 0.

2. State \{scan mobility pattern\}, state scan mobility pattern suatu saat dapat tercapai apabila kondisi dari mobile station berada pada state no scan dan terdapat pola pergerakan yang sukses pada tabel mobility pattern. Jika keseluruhan target base station yang diseleksi tidak dapat menerima mobile station, maka proses yang terjadi selanjutnya adalah menuju kondisi kegagalan state fail atau menuju kondisi scan konvensional. Sebaliknya jika target base station dapat menerima permintaan handoff dari mobile station maka kondisi selanjutnya akan mencapai cell switch dan tabel mobility pattern diupdate berdasarkan pola kesuksesan handover. State ini diberikan penomoran sebagai state 1 .

State scan konvensional\}, metode scanning konvensional memiliki proses yang lebih banyak dibandingkan dengan scanning mobility pattern. Pemilihan target base station kemudian dilakukan pada daftar neighbor base station yang ada pada pesan mobile scanning report. Neighbor base station diurutkan berdasarkan kualitas sinyal yang paling tinggi. Setelah itu dipilih target base station dengan kualitas sinyal terbaik. Tahap berikutnya adalah sinkronisasi dari target base station yang terdiri dari proses penerimaan informasi physical layer channel, contention resolution, dan permintaan ranging. State ini diberikan penomoran sebagai state 2.

3. State \{cell switch\}, Pada state cell switch ini terdapat beberapa proses yang dilakukan oleh mobile station yaitu network entry, mengakhiri konteks mobile station, dan konektivitas IP. State cell switch berarti mobile station sudah dapat menggunakan jaringan pada target base station tujuan handoff. Sehingga transisi yang terjadi hanya menuju state no scan. State ini diberikan penomoran sebagai state 3.

4. State $\{$ fail $\}$, state fail menunjukkan kegagalan yang terjadi pada proses handover. Kondisi ini dapat tercapai dari semua state yang terjadi pada perilaku mobile station, kecuali state cell switch. Pada penelitian ini, ketika proses handover mengalami kegagalan, mobile station diasumsikan tidak diperhatikan lagi. state ini dinyatakan sebagai arbsorbing state, yaitu suatu state yang tidak memiliki transisi keluar. State ini diberikan penomoran sebagai state 4.

\subsubsection{State space model CTMC dari perilaku channel target base station}

Perubahan jumlah dari channel pada target base station ini diperhatikan berdasarkan laju birth atau bertambahnya jumlah channel yang digunakan dan laju death atau berkurangnya jumlah channel yang digunakan. State space dari perilaku channel ini bersifat diskrit yang terdiri dari $0,1,2, \ldots, N$ yang artinya berjumlah $N+1$ dari $N$ buah channel yang dimiliki. Transisi yang dimungkinkan hanya menuju channel $n+1$ maupun $n-1$. Misalnya, jika kondisi channel berada state 10 (jumlah channel yang digunakan 10 buah) maka transisi dari state ini hanya menuju state 11 atau state 9. Transisi tersebut tidak berlaku pada state 0 dan state $N$. Untuk state 0 transisi yang mungkin hanya menuju state 1 , hal tersebut dikarenankan state 0 menandakan bahwa tidak ada channel yang digunakan oleh mobile station. Sedangkan untuk state $N$ transisi yang dimungkinkan hanya transisi yang menuju state $N-1$, karena ketika 
keseluruhan channel telah digunakan maka mobile station yang melakukan handover menuju channel tersebut

akan ditolak.

\subsubsection{State space model CTMC handover pada jaringan WiMAX}

State space dari model CTMC skema handover merupakan kombinasi dari model CTMC perilaku mobile station dan model CTMC dari channel target base station. Sebagai contohnya ketika proses handover dimulai dalam unit waktu 0 state model CTMC skema handover berada pada kondisi mobile station tidak melakukan scanning (state no scan) dan channel pada target base station belum ada yang digunakan (state 0). Dalam waktu tertentu akan terjadi transisi dari model CTMC skema handover, baik karena perubahan state dari mobile station atau channel pada target base station. Perubahan yang dialami mobile station maupun channel akan mengalami race condition (yang lebih cepat melakukan transisi) sesuai dengan laju transisi yang dimilki setiap state.

\subsection{Transisi state}

State space dari represntasi state memiliki keterkaitan satu sama lain. Perubahan kondisi

dari sebuah state menuju state lainnya dihubungkan dengan transisi. Transisi memiliki waktu dan probabilitas yang disebut dengan laju transisi. Waktu yang diperlukan untuk melakukan transisi ditinggalkan pada sebuah state sebelum melakukan transisi menuju state lain terdistribusi secara eksponensial dan ketika proses meninggalkan state $i$ untuk menuju ke state $j$ memerlukan probabilitas $p_{i j}$ [8]. Penentuan probabilitas $\left(p_{i j}\right)$ untuk produk CTMC perilaku mobile station akan mengikuti distribusi multinomial karena setiap pemilihan state bergantung kemunculan dari target base station hasil seleksi pada tabel mobility pattern.

\subsubsection{Transisi model CTMC perilaku mobile station}

Ilustrasi model CTMC perilaku yang dilakukan oleh mobile station dapat diperhatikan pada Gambar 1.

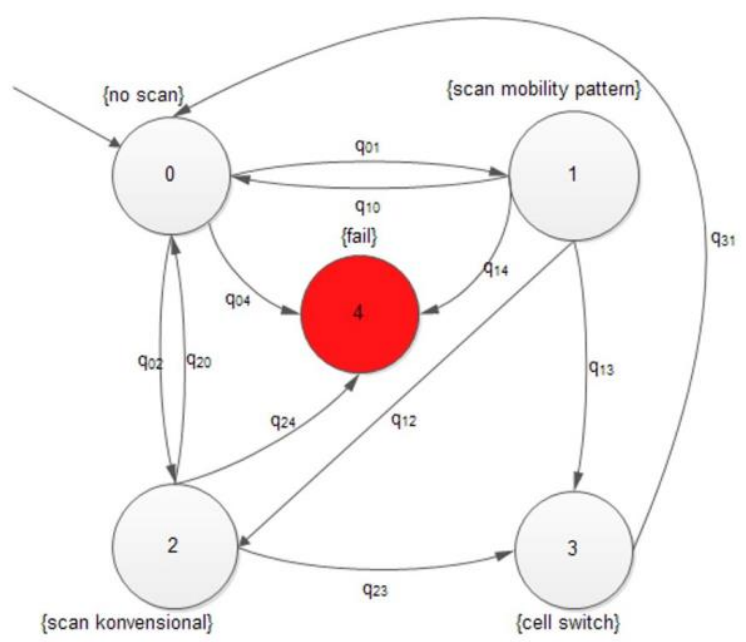

Gambar 1 Model CTMC perilaku mobile station berikut:

Dari tiap-tiap state yang ditunjukkan akan memiliki transisi yang ditentukan sebagai

1. State no scan, laju transisi dari proses yang akan terjadi setelah berada pada proses no scan terdiri dari laju transisi state $\{$ no scan\} menuju state $\{$ scan mobility pattern $\}\left(q_{01}\right)$, laju transisi state $\{$ no scan $\}$ menuju state $\{$ scan konvensional $\}\left(q_{02}\right)$, laju transisi state $\{$ no scan $\}$ menuju state $\{$ fail $\}\left(q_{04}\right)$.

IJCCS Vol. 10, No. 1, January 2016: $81-92$ 
2. State scan mobility pattern, laju transisi yang dimiliki oleh state scan mobility pattern terdiri dari transisi state \{scan mobility pattern\} menuju state $\{$ scan konvensional\} $\left(q_{12}\right)$, laju transisi state $\{$ scan mobility pattern $\}$ menuju state $\{$ cell switch $\}\left(q_{13}\right)$, laju transisi state $\{$ scan mobility pattern $\}$ menuju state $\{$ fail $\}\left(q_{14}\right)$.

3. State scan konvensional, laju transisi yang dimiliki oleh state scan konvensional terdiri dari laju transisi state $\left\{\right.$ scan konvensional\} menuju state $\{$ no scan $\}\left(q_{20}\right)$, laju transisi state $\left\{\right.$ scan konvensional\} menuju state $\{$ cell switch $\}\left(q_{23}\right)$, laju transisi state $\{$ scan konvensional $\}$ menuju state $\{$ fail $\}\left(q_{24}\right)$.

4. State cell switch, laju transisi yang dimiliki oleh state cell switch hanya terdiri dari transisi dari state $\{$ cell switch $\}$ menuju state $\{$ no scan $\}\left(q_{30}\right)$

5. State fail tidak memiliki transisi karena merupakan absorbing state.

Nilai laju transisi dari model CTMC dari mobile station merupakan perkalian dari sojourn time pada state tersebut dikalikan dengan probabilitas transisi menuju state tujuan. Contoh salah satu penentuan laju transisi model CTMC mobile station dari state 0 menuju state 1:

$$
\begin{aligned}
q_{01} & =v_{i} \times p_{i j} \\
& =\lambda_{1} \times p_{01} \\
& =1 / 522855 \times 0.75 \\
& =1.4344321 e-6
\end{aligned}
$$

Untuk niai laju transisi dari model CTMC perilaku mobile station diberikan pada Tabel 1 sebagai berikut:

Tabel 1 Laju transisi model CTMC perilaku mobile station

\begin{tabular}{|c|c|l|l|l|l|}
\hline No & Transisi & $\begin{array}{c}\text { Laju transisi } \\
\left(\mathrm{q}_{\mathrm{ii}}\right)\end{array}$ & No & Transisi & $\begin{array}{c}\text { Laju transisi } \\
\left(\mathrm{q}_{\mathrm{ij}}\right)\end{array}$ \\
\hline 1 & $\{0,1\}$ & $1.4344321 \mathrm{e}-6$ & 11 & $\{2,3\}$ & 0.011574419 \\
\hline 2 & $\{0,2\}$ & $4.0967770 \mathrm{e}-7$ & 12 & $\{2,4\}$ & 0.011213953 \\
\hline 3 & $\{0,3\}$ & 0 & 13 & $\{3,0\}$ & 0.0333333 \\
\hline 4 & $\{0,4\}$ & $6.8278968 \mathrm{e}-8$ & 14 & $\{3,1\}$ & 0 \\
\hline 5 & $\{1,0\}$ & $6.0606061 \mathrm{e}-4$ & 15 & $\{3,2\}$ & 0 \\
\hline 6 & $\{1,2\}$ & 0.0055091 & 16 & $\{3,4\}$ & 0 \\
\hline 7 & $\{1,3\}$ & 0.0150818 & 17 & $\{4,0\}$ & 0 \\
\hline 8 & $\{1,4\}$ & 0.003651 & 18 & $\{4,1\}$ & 0 \\
\hline 9 & $\{2,0\}$ & $4.6511628 \mathrm{e}-4$ & 19 & $\{4,2\}$ & 0 \\
\hline 10 & $\{2,1\}$ & 0 & 20 & $\{4,3\}$ & 0 \\
\hline
\end{tabular}

\subsubsection{Transisi model CTMC channel sebuah target base station}

Perubahan kondisi channel mengikuti ciri-ciri proses birth-death yang merupakan varian dari Continuous-Time Markov Chain (CTMC). Jumlah channel yang berubah dalam suatu interval waktu "t" yang sangat kecil hanya dapat bertambah atau berkurang satu. Tidak dimungkinkan dalam sebuah interval waktu t yang singkat channel yang digunakan bertambah maupun berkurang dua atau lebih secara bersamaan. Hal tersebut dapat dilihat pada Gambar 2. Sesuai dengan penelitian yang dilakukan oleh Untuk jumlah channel yang tersedia pada target base station [9], tentang perilaku perubahan channel dalam skema soft handoff dari CDMA selular, transisi yang keluar dari suatu state $n$ menuju state $n+1$ terdistribusi secara eksponensial [6]. Hal ini didatangkan dari suatu asumsi kedatangan yang bersifat memoryless property yaitu jumlah kedatangan yang akan datang hanya akan dipengaruhi oleh keadaan saat ini dan tidak dipengaruhi oleh keadaan sebelumnya. 


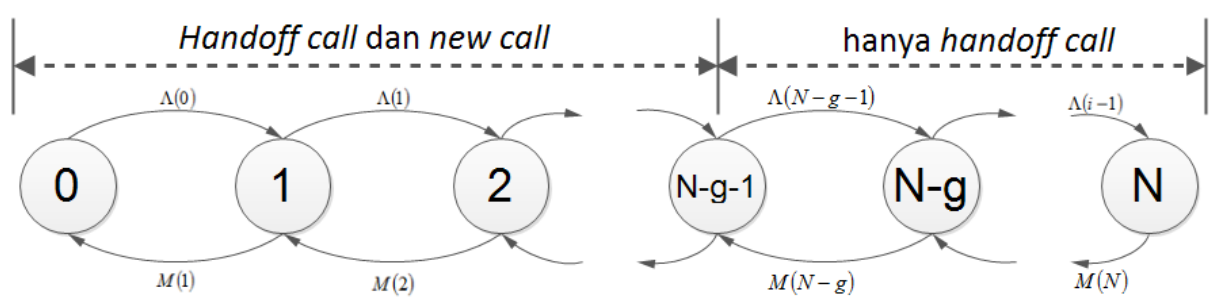

Gambar 2 Model CTMC channel target base station

Jumlah dari kedatangan tersebut setiap interval waktu akan berubah-ubah, tidak dapat kita ketahui. Untuk kedatangan pada channel diasumsikan terdapat dua jenis kedatangan yang berbeda dengan waktu laju kedatangan yang berbeda pula, yaitu kedatangan handoff dengan laju $\lambda_{h}$ dan kedatangan yang merupakan suatu panggilan baru dengan laju $\lambda_{c}$. Laju kedatangan dari new call akan dibatasi sesuai dengan guard yang diberikan sesuai dengan prioritas yang ditentukan [10]. Waktu yang dibutuhkan untuk meninggalkan suatu state akan terdistribusi secara eksponensial dengan rate $\mu_{n}$.

\subsubsection{Transisi model CTMC skema handover pada jaringan WiMAX}

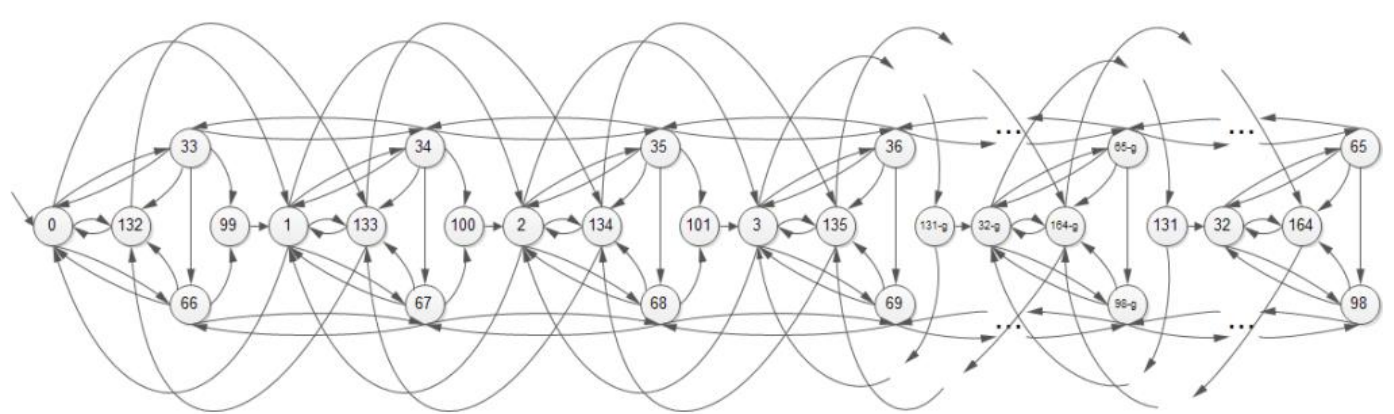

Gambar 3 Diagram state transisi model CTMC skema handover pada jaringan WiMAX

Model CTMC dari skema handover jaringan WiMAX merupakan kombinasi dari model CTMC perilaku mobile station dan model CTMC perilaku channel seperti yang telah dipaparkan pada representasi state space. Transisi yang terjadi pada model CTMC skema handover pada jaringan WiMAX ini juga merupakan kombinasi dari dua buah model tersebut. Dalam model CTMC skema handover yang dibangun ini state inisialnya adalah kombinasi state no scan pada model CTMC dengan state 0 pada model CTMC channel. Pada model CTMC dari skema handover state inisial ini diberi penomoran sebagai state 0 . Jika dalam observasi waktu tertentu terjadi perubahan jumlah channel dari 0 menjadi 1 maka state pada model CTMC handover jaringanWiMAX akan bertransisi menuju state 1. Ilustrasi dari transisi yang terjadi pada model CTMC skema handover pada jaringan WiMAX ditunjukkan pada Gambar 3.

Penamaan untuk setiap state pada Gambar 3 adalah nomor diskrit. Penamaan tersebut dilakukan agar model yang dibangun terlihat lebih sederhana. Pada penomoran tersebut terbentuk suatu pola, jika dalam model CTMC skema handover jaringan WiMAX yang mengalami perubahan kondisi adalah mobile station maka transisi selanjutnya adalah state $n$ dari model CTMC mobile station dikalikan dengan jumlah total state pada model CTMC perilaku channel.

\subsection{Verifikasi Properti Kualitatif dan Kuantitatif}

Verifikasi dari sistem yang menunjukkan probabilitas dapat difokuskan pada properti kualitatif, kuantitatif, atau keduanya [4] Properti kualitatif menunjukkan bahwa suatu kondisi yang baik akan terjadi atau kondisi yang buruk tidak akan pernah terjadi. Verifikasi properti 
kualitatif yang dilakukan pada penelitian ini adalah verifikasi mengenai reachability dari setiap perubahan kondisi dari perilaku mobile station pada model CTMC skema handover jaringan WiMAX. Properti kuantitatif menunjukkan bahwa sistem memiliki probabilitas mencapai kondisi tertentu dalam batas waktu $\mathrm{T}$ yang ditentukan.

\section{HASIL DAN PEMBAHASAN}

\subsection{Properti Kualitatif}

Model CTMC skema handover harus menjamin tercapainya suatu transisi menuju kondisi scan mobility pattern, scan konvensional cell switch, dan fail yang dialami oleh mobile station. Kondisi tersebut harus dicapai dari kondisi no scan yang merupakan kondisi awal mobile station dalam melakukan handover. Untuk itu verifikasi terhadap properti reachability tiap-tiap state perlu dilakukan. Verifikasi dilakukan dengan mengubah spesifikasi properti reachability dalam bentuk CTL menjadi bahasa PRISM.

Berdasarkan verifikasi yang dilakukan, terbukti bahwa model yang dibangun memenuhi properti reachability pada keseluruhan kondisi yang dialami oleh mobile station. Properti yang terpenuhi tersebut menunjukkan bahwa model yang dibangun dengan produk CTMC dapat berperilaku sesuai perilaku handover dengan mobility pattern pada jaringan WiMAX dalam penelitian [2]. Hasil verifikasi dari spesifikasi properti tersebut ditunjukkan pada Gambar 4.

\subsection{Properti Kuantitatif}

Pendekatan properti kuantitatif yang dilakukan dalam penelitian ini memperhatikan beberapa hal yaitu verifikasi probabilitas blocking terhadap permintaan handoff (kapasitas channel mencapai batas maksimal), verifikasi probabilitas pemilihan metode scanning, dan verifikasi probabilitas keberhasilan metode scanning.

\subsubsection{Verifikasi probabilitas blocking terhadap permintaan handoff (Kapasitas channel mencapai batas maksimal)}

Dalam verifikasi properti ini yang diperhatikan adalah bagaimana probabilitas channel yang digunakan mencapai jumlah maksimal dari channel yang tersedia. Kondisi channel ini dipengaruhi oleh laju kedatangan dan laju sebuah mobile station meninggalkan target base station. Laju kedatangan mobile station pada target base station diuji dengan tiga kondisi. Laju kedatangan yang lebih besar dari laju mobile station meninggalkan target base station, laju kedatangan yang besarnya sama dengan laju mobile station meninggalkan target base station, dan laju kedatangan yang lebih kecil dari laju mobile station meninggalkan target base station.

Probabilitas penggunaan channel mencapai batas maksimal diperhatikan berdasarkan jumlah channel yang ditentukan pada analisis model yaitu sebesar 32. Pada PRISM untuk mengetahui probabilitas channel mencapai kapasitas maksimal dalam setiap interval waktu diverifikasi berdasarkan penerjemahan dari spesifikasi property dalam bentuk CSL menjadi bahasa PRISM yaitu "P =?[F[T; T]"full"]". Hasil verifikasi dari spesifikasi properti tersebut ditunjukkan pada Gambar 4.

Ketiga buah kurva yang diperlihatkan memiliki perbedaan nilai laju kedatangan dan laju meninggalkan channel target base station. Dalam keterangan yang tertera pada Gambar 4 penandaan setiap kurva diberikan pelabelan berdasarkan laju kedatangan $(\lambda)$ dan laju meninggalkan target base station $(\mu)$. Sesuai dengan kodisi tersebut, penggunaan channel hingga mencapai batas maksimal diobservasi berdasarkan tiga buah kondisi. Kondisi yang pertama adalah dengan penentuan laju kedatangan lebih tinggi dari laju meninggalkan target base station $(\lambda>\mu)$. Kondisi yang kedua adalah dengan laju kedatangan yang nilainya sama dengan laju meninggalkan target base station $(\lambda=\mu)$. kondisi yang terakhir adalah dengan laju kedatangan yang nilainya lebih kecil dari laju meninggalkan target base station $(\lambda<\mu)$. 


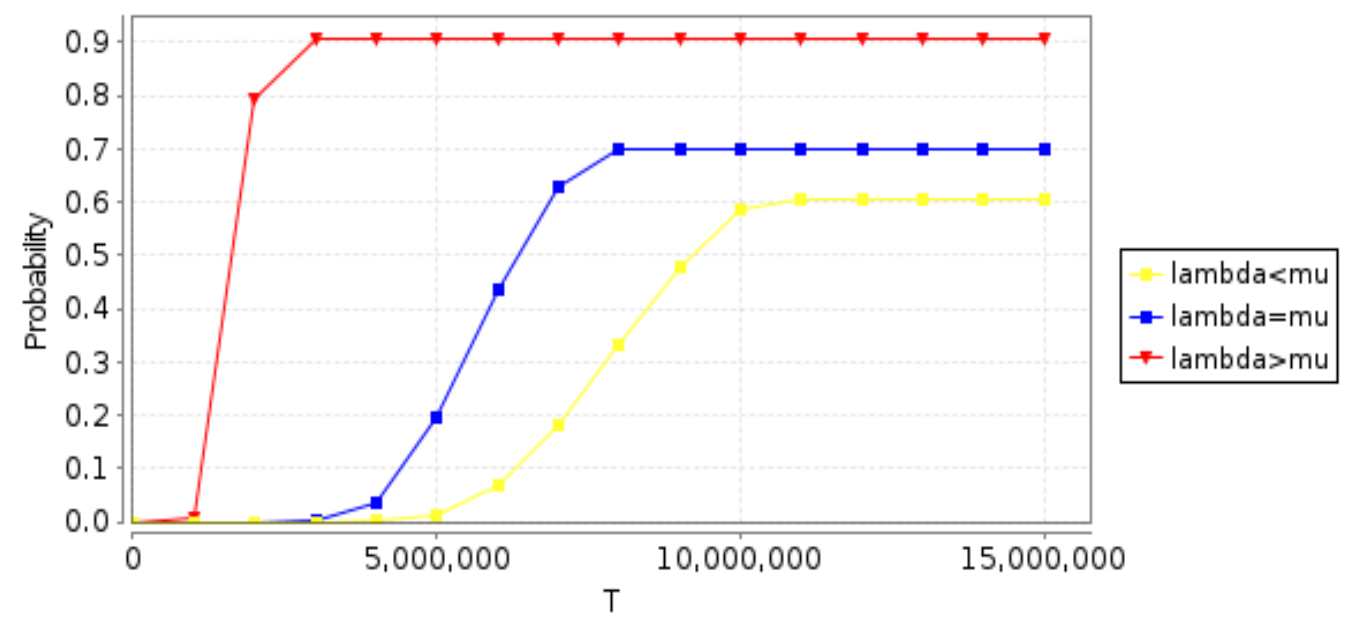

Gambar 4 Probabilitas dari sebuah channel untuk mencapai kapasitas maksimal

\subsubsection{Probabilitas pemilihan metode scanning}

Spesifikasi properti untuk pemilihan metode scanning dibagi menjadi dua kasus. Kasus yang pertama adalah spesifikasi properti untuk pemilihan metode scanning target base station yang menggunakan mobility patern. Kasus yang kedua adalah spesifikasi properti pemilihan metode scanning yang konvensional.

Verifikasi dilakukan terhadap properti "P=? [F[T,T]"mob"]" untuk memperhatikan probabilitas terpilihnya scan mobility pattern. Properti tersebut memiliki semantik "berapa probabilitas dari pemilihan metode scanning yang menggunakan mobility pattern dalam interval waktu T,T". P=? memiliki makna "berapa nilai probabilitas". "F[T,T]" eventually/future atau suatu saat dalam interval T,T. "mob" merupakan fungsi pelabelan untuk state yang menunjukkan mobile station berada dalam kondisi scan mobility pattern. Verifikasi dilakukan dalam tiap 50 unit waktu dengan interval 0 sampai dengan 750 unit waktu. Verifikasi spesifikasi properti "P=? [F[T,T] "konv"]" dilakukan untuk metode scanning konvensional. Perbedaan dengan spesifikasi properti dari pemilihan metode scanning yang menggunakan mobility pattern hanya terletak pada fungsi pelabelan. Hasil verifikasi dari properti pemilihan metode scanning ditunjukkan dengan Gambar 5.

Nilai probabilitas yang ditunjukkan pada Gambar 5 sangat kecil, hal ini terjadi karena transisi yang terjadi ketika model CTMC skema handover berada pada state yang menunjukkan kondisi no scan dari mobile station terdapat transisi keluar yang tidak menuju kondisi scanning. Misalkan pada state 0 transisi keluar dapat menuju ke state 1 yang artinya bertambahnya jumlah channel yang digunakan. Nilai probabilitas dari pemilihan metode scanning yang menggunakan mobility pattern meningkat hingga 0.0000675 pada waktu observasi ke-300. Setelah 300 unit waktu nilai probabilitas tidak berubah yang menunjukkan probabilitas steady state dari pemilihan metode scanning yang menggunakan mobility pattern.

Perubahan nilai probabilitas dalam setiap waktunya ditunjukkan dengan kurva yang berwarna biru. Nilai probabilitas dari pemilihan metode scanning mengalami peningkatan dalam tiap waktu. Namun setelah 500 unit waktu pengamatan nilai probabilitas properti tersebut tidak mengalami peningkatan yang menunjukkan probabilitas steady-state. Nilai probabilitas steady statenya adalah 0.0000648 . 


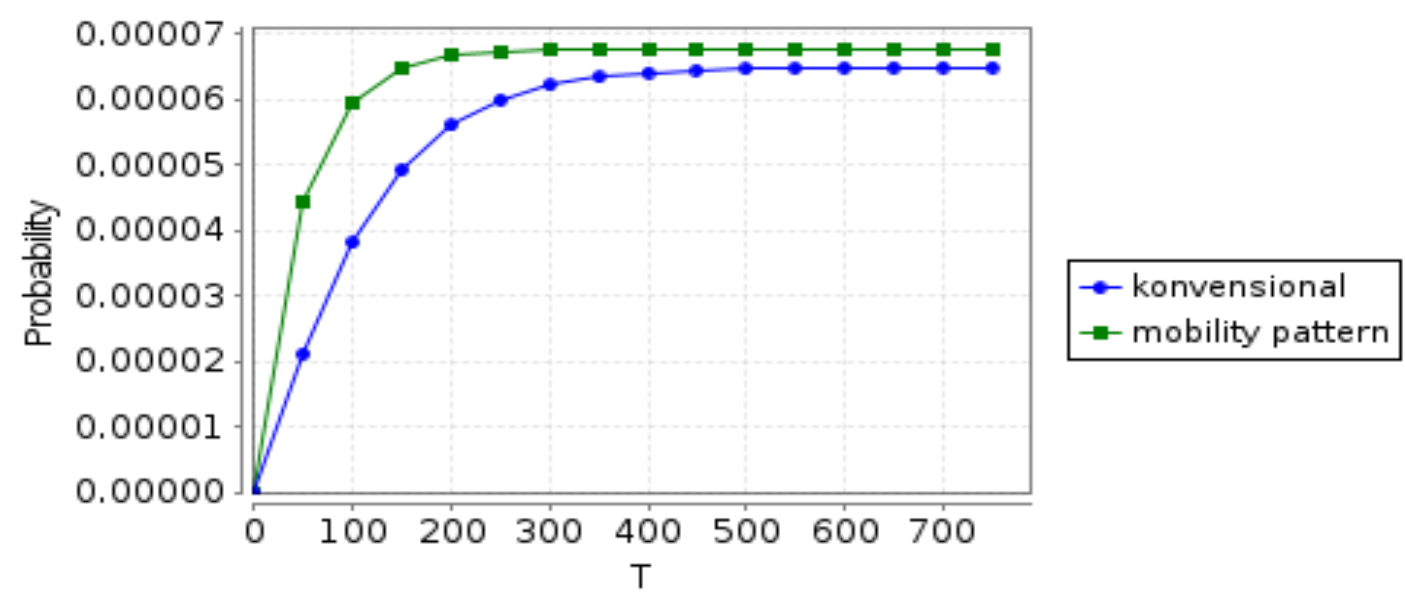

Gambar 5 Probabilitas pemilihan metode scanning

\subsubsection{Probabilitas keberhasilan dari scanning}

Untuk mengetahui keberhasilan suatu metode handover yang digunakan verifikasi dilakukan untuk mengetahui probabilitas mencapai state cell switch untuk mengetahui keberhasilan metode handover. Pada percobaan kali ini yang dilakukan adalah membandingkan probabilitas yang ditunjukkan oleh keberhasilan state scan mobility pattern maupun state scan konvensional untuk mencapai state cell switch, scan konvensional, maupun fail.

\section{Scanning Mobility pattern}

Untuk mengetahui nilai probabilitas keberhasilan tersebut dilakukan verifikasi terhadap spesifikasi properti "berapa probabilitas eventually/future atau suatu saat mencapai kondisi cell switch dalam interval waktu T,T". Dalam bahasa PRISM dinyatakan dengan "P=? ["mob" $\mathrm{U}^{\mathrm{T}}$ "switch"]". Selain memperhatikan keberhasilan, verifikasi juga dilakukan untuk perubahan kondisi dari scan mobility pattern menjadi scan konvensional, gagal atau kondisi fail, dan batal melakukan handover (transisi menuju no scan). Verifikasi yang dilakukan pada perubahan kondisi menjadi scan konvensional ditunjukkan dengan spesifikasi properti " $\mathrm{P}=$ ? ["mob" $\mathrm{U}^{\mathrm{T}}$ "konv"]". Sedangkan spesifikasi properti untuk kondisi fail dan no scan secara berturut-turut ditunjukkan dengan " P=? ["mob" U "fail"]" dan " P=? ["mob" U "noscan"]".

Berdasarkan verifikasi yang dilakukan, terlihat pada Gambar 6 bahwa state scan mobility pattern lebih dominan melakukan transisi menuju state cell switch. Nilai probabilitas keberhasilan penggunaan metode mobility pattern tidak mengalami perubahan setelah 300 unit waktu sebesar $70 \%$. Namun pada grafik tersebut juga terdapat kurva yang menunjukkan kegagalan metode mobility pattern untuk melakukan handover kemudian memilih metode konvensional dengan distribusi probabilitas yang tidak berubah sebesar $24 \%$.

\section{Metode scanning konvensional}

Verifikasi ditujukan untuk mengetahui nilai probabilitas keberhasilan dan kegagalan dari metode scanning konvensional. Spesifikasi property tiap-tiap kondisi tersebut secara berurutan ditunjukkan dengan " $\mathrm{P}=$ ? ["konv" $\mathrm{U}^{\mathrm{T}}$ "switch"]". dan " $\mathrm{P}=$ ? ["konv" $\mathrm{U}^{\mathrm{T}}$ "fail"]". ". Lama waktu observasi yang dilakukan adalah 0,500 .

Untuk verifikasi keberhasilan proses handover dengan metode scanning konvensional ditunjukkan dengan kurva Gambar 7 yang diberi pelabelan "konvensional". Sedangkan untuk kegagalan diberikan pelabelan "fail". Verifikasi terhadap properti keberhasilan menghasilkan nilai probabilitas yang terus meingkan hingga mencapai 94\%. Hal tersebut menunjukkan peluang kesuksesan melakukan handover sangat besar jika metode yang digunakan adalah metode konvensional. Berdasarkan verifikasi yang dilakukan, dapat dilihat bahwa metode 
konvensional memiliki hasil yang lebih baik daripada metode mobility pattern dalam proses handover.

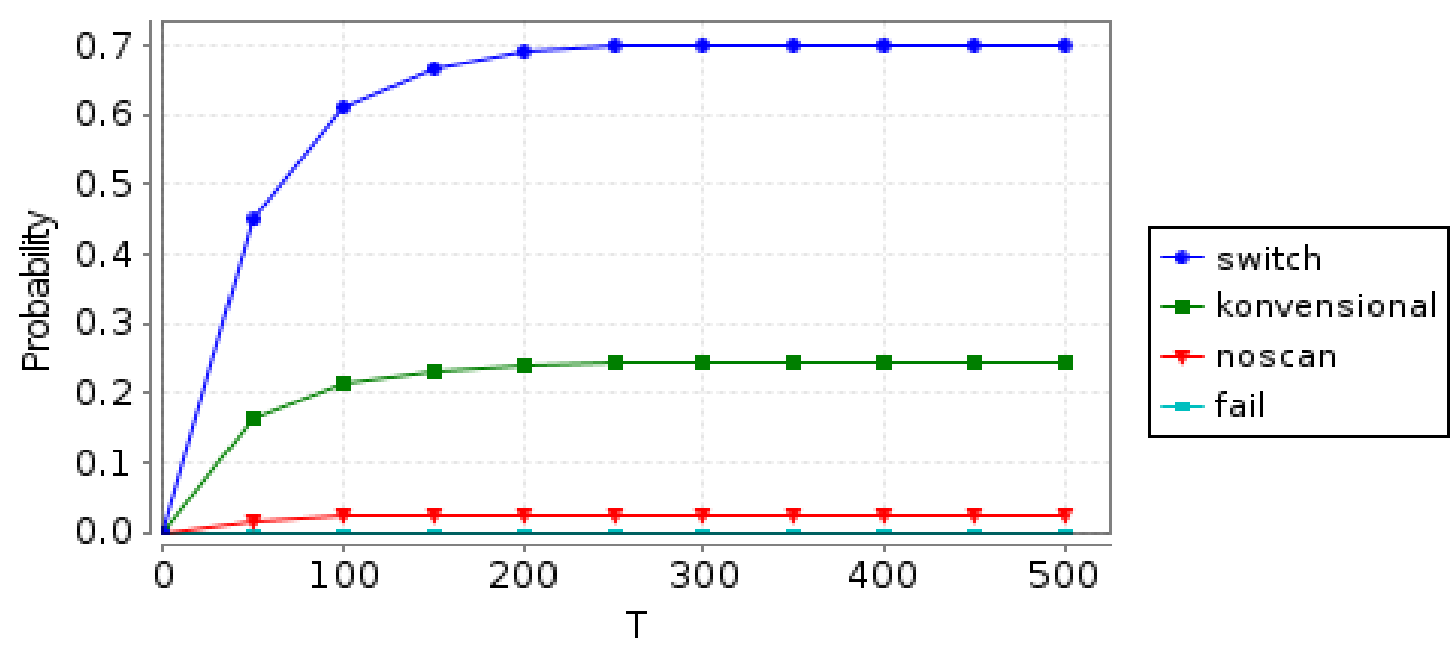

Gambar 6 Probabilitas keberhasilan metode scanning yang menggunakan mobility pattern

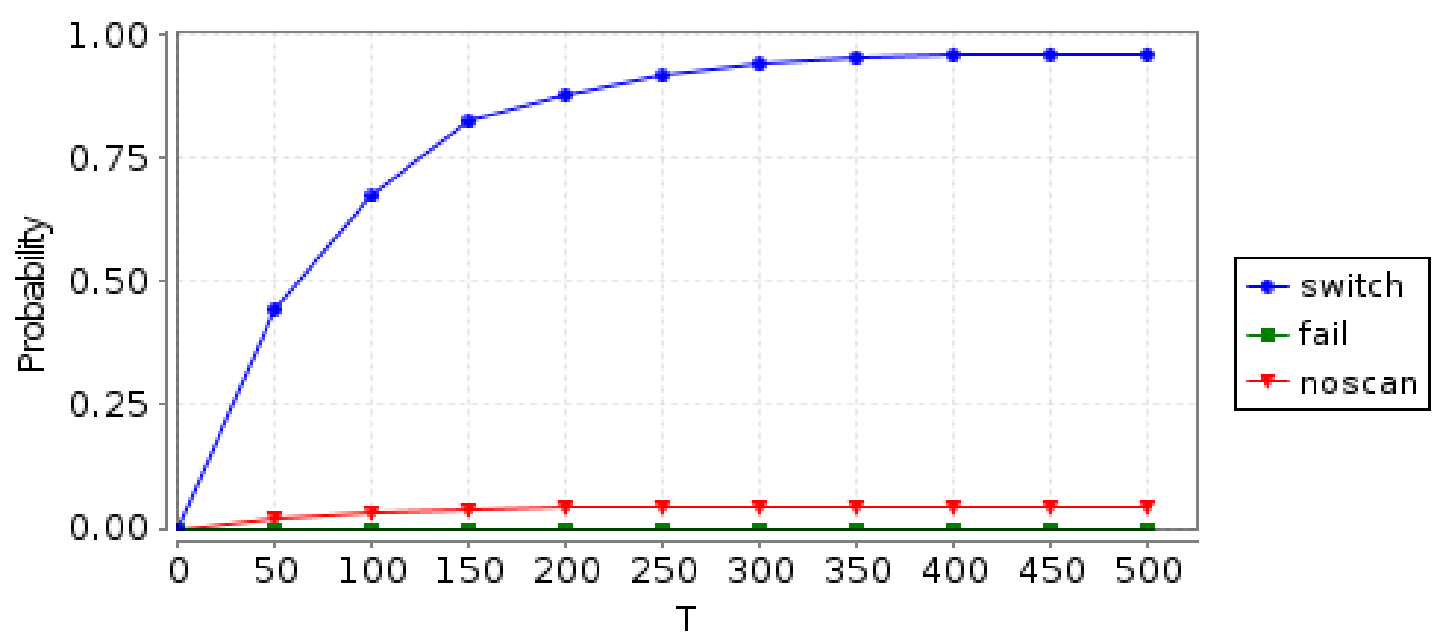

Gambar 7 Probabilitas keberhasilan metode scanning konvensional

\section{KESIMPULAN}

Berdasarkan pembahasan tentang pemodelan dan verifikasi formal pengaruh mobility pattern terhadap handoff latency pada jaringanWiMAX yang telah diuraikan pada bab-bab sebelumnya, maka dapat ditarik beberapa kesimpulan sebagai berikut :

1. Model handover dengan mobility pattern dapat dibangun dengan pendekatan Continuous-Time Markov Chain pada tool PRISM sesuai dengan perilaku stokastik yang ditunjukkan oleh sistem dari model yang dibangun pada [2].

2. Verifikasi formal terhadap properti-properti yang berkaitan dengan handover pada jaringan WiMAX menunjukkan bahwa $70 \%$ dari MS yang melakukan scanning 
dengan mobility pattern sukses melakukan handover, $24 \%$ diantaranya melakukan scanning konvensional akibat kesalahan dalam penentuan TBS sehingga handoff latency yang dihasilkan lebih besar jika dibandingkan dengan sistem yang hanya menggunakan metode scanning konvensional.

3. Secara keseluruhan metode handover dengan mobility pattern dapat mengurangi handoff latency pada model jaringan WiMAX.

\section{SARAN}

Dalam penelitian ini dihasilkan data berupa distribusi probabilitas untuk mengetahui pengaruh mobility pattern terhadap handoff latency pada jaringan WiMAX. Namun penelitian yang dilakukan hanya memperhatikan sebuah TBS sebagai tujuan handover. Serta, properti energi efisiensi tidak diperhatikan dalam penelitian ini. Dari uraian tentang kekurangan penelitian ini dan apa yang belum dilakukan dalam penelitian ini, maka untuk penelitian yang akan datang diharapkan :

1. Melakukan penelitian dengan menambahkan jumlah TBS.

2. Menambahkan properti energi efisiensi sehingga penyebab kegagalan handover yang bukan merupakan kesalahan sistem jaringan WiMAX dapat diketahui.

\section{DAFTAR PUSTAKA}

[1] Ahmadi S (2011). Mobile WiMAX A System Approach to Understanding IEEE $802.16 \mathrm{~m}$ Radio Access Technology, Academic Press.

[2] Zhang Z, Pazzi R, Boukerche A and Lanfieldt B (2010). Reducing Handoff Latency for WiMAX Networks Using Mobility patterns, in Wireless Communications and Networking Conference (WCNC), 2010 IEEE, IEE, pp. 1-6.

[3] Khan A N, Anwer W and Munir E U (2013). Handover Techniques in Mobile WiMAX Networks: Analysis and Comparison, in Middle-East Journal of Scientific Research, Vol. 15, IDOSI Publications, pp. 1599-1605.

[4] Baier C and Katoen J (2008). Principles of model checking, MIT Press.

[5] Chowdhurry P, Kundu A, Misra I S and Sanyal S K (2012). Load Balancing with Reduce Unnecessary Handoff in Energy Efficient Macro/Femto-cell Based BWA Network, International Journal of Wireless \& Mobile Networks (IJWMN) 4(3), 105-118.

[6] Ma X, Cao Y, Liu Y and Triverdi K (2006). Modeling and performance analysis for soft handoff schemes in CDMA cellular systems, Vehicular Technology, IEEE Transactions 55, 670-680.

[7] Kirsal Y and Gemikonakli O (2009). Approaches to Modelling and Analysis for Performability Evaluation of Handoff Schemes in Wireless Cellular Networks, Computational Intelligence, Modelling and Simulation CSim 09 .

[8] Ross S M (2010). Introduction to Probability Model 10th Edition, Aca.. 
[9] Trivedi K S, Ma X and Dharmaraja S (2003). Performability Modelling of Wireless Communication Systems, in International Journal of Communication Systems, number 16, John Wiley \& Sons, Ltd, pp. 561-567.

[10] Yu Y (2009), Handover Performance in the Mobile WiMAX Netrworks, Master's thesis, University of South Florida. 